\title{
RESEARCH PAPER \\ The physiological and growth response of Acacia caven under water stress and the application of different levels of biosolids
}

\author{
Sergio Donoso ${ }^{1}$, Karen Peña-Rojas ${ }^{1}$, Cristian Pacheco ${ }^{1}$, Sergio Durán ${ }^{1}$, \\ Rómulo Santelices ${ }^{2}$ and Cristóbal Mascaró ${ }^{1}$ \\ ${ }^{1}$ Facultad de Ciencias Forestales y de Conservación de la Naturaleza Universidad de Chile. Casilla 9206 , \\ Santiago, Chile. \\ ${ }^{2}$ Facultad de Ciencias Agrarias y Forestales, Universidad Católica del Maule. Casilla 617, Talca, Chile.
}

\begin{abstract}
S. Donoso, K. Peña-Rojas, C. Pacheco, S. Durán, R. Santelices, and C. Mascaró. 2015. The physiological and growth response of Acacia caven under water stress and the application of different levels of biosolid. Cien. Inv. Agr. 42(2):273-283. Acacia caven (Mol.) Mol. (Leguminosae), generally known as "espino," is one of the most common tree species in the Mediterranean region of Chile. This species grows in nutritionally poor soils with low water availability during the summer, so it is very difficult for new seedlings to become established. To investigate the effects of water restriction and the potential benefit of the application of biosolids (sludge bio-dried to $25 \%$ moisture) on the growth of the plant, a completely random, two $\mathrm{x}$ three factorial design was carried out in controlled nursery conditions under two irrigation regimes (well-watered plants and controlled water restriction) and three biosolid application rates $(0: 100,10: 90$ and 20:80) in a clay substrate. Physiological evaluations (predawn water potential, photosynthesis and gas exchange) were performed at representative times along the water restriction gradients and supplemented with measurements of growth and biomass distribution. Once plants entered the water restriction phase, those in the biosolidtreated substrate exhibited better hydration compared to plants in the untreated substrate. This was attributed to the increased organic matter content as well as to changes in the textural characteristics of the original substrate that increased its capacity to deliver water to the plants. Additionally, the application of biosolids promoted shoot and leaf growth in well-watered plants, increasing the shoot:root ratio, which could be a disadvantage under water stress.
\end{abstract}

Key words: Biomass, predawn water potential, photosynthesis, shoot:root ratio, water restriction.

\section{Introduction}

The growing worldwide interest in improving the quality of wastewater has progressively increased

Received March 5, 2014. Accepted April 10, 2015. Corresponding author: sedonoso@uchile.cl the amount being treated. Biosolids are a byproduct of water treatment, and they are mainly composed of organic matter, macro- and micronutrients, and some trace elements. In Chile, the production of biosolids has significantly increased over the last decade, making disposal a prominent environmental issue. Currently, there are several alternatives for the 
disposal of biosolids: landfill deposits, incineration and increasing crop production (Paz et al., 2007), and several studies have shown that biosolids have a positive effect on the growth of plants (Pascual et al., 2004; Antolin et al., 2010; Valdecantos et al., 2011). Therefore, one potential solution to the environmental problem of biosolids is their application as fertilizer in forest plantations to increase the amount of organic matter and improve the capacity of the soil to store water (Cogger et al., 2000).

These benefits might be crucial to reforestation efforts in Mediterranean areas because one of the main problems affecting seedlings during their establishment phase is high mortality, which occurs as a result of water deficit, one of the most critical environmental stress factors for Mediterranean species (Villar-Salvador et al., 2004; Pardos et al., 2005). Water deficit significantly affects plant photosynthetic and water performance and eventually negatively impacts biomass growth and accumulation. Biosolids are a source of readily available organic matter (Fuentes et al., 2007a) that can be used to improve plant establishment (Henry et al., 1994; Larcheveque et al., 2006). This is of special interest to the use of Acacia caven (Mol.) ("espino") for reforestation in central Chile as this process is generally performed on nutritionally poor soils with reduced water availability, which makes plant establishment very difficult. To date, few studies have examined the effects of biosolid application on the physiological response of forest species under restricted water conditions; most have instead focused on the nutritional effects. The objective of this study was to describe the physiological and growth responses in espino plants subjected to water stress under different levels of biosolid application.

\section{Materials and methods}

\section{Study site and experimental design}

The trial was conducted at the University of Chile's experimental nursery, Antumapu (33 $34^{\circ} \mathrm{S}$ and $70^{\circ} 37^{\prime} \mathrm{W}$, altitude $420 \mathrm{~m}$.), during the summer of 2011. At this time of the year, the monthly average maximum temperature ranges from 28.7 to $20.7^{\circ} \mathrm{C}$, and the minimum monthly temperature averages 15.0 to $7.9^{\circ} \mathrm{C}$. Total rainfall during the study period was $0 \mathrm{~mm}$.

One month before the start of the experiment, 105 two-year-old espino plants were selected based on their height (average of $34 \mathrm{~cm}$ ) and root collar diameter (average of $4.5 \mathrm{~mm}$ ) and placed in $10-\mathrm{L}$ pots. Thirty-five plants were assigned to each of three substrate treatments: a control group without added biosolids (T-0); 90\% soil with $10 \%$ of the biosolid treated substrate (T-10), and $80 \%$ soil with $20 \%$ of the biosolid treated substrate (T-20). The soil (Rungue series, Vertic Haploxerolls (Mollisols), CIREN, 1996) (Table 1) was collected from El Rutal farm, which is located $60 \mathrm{~km}$ north of Santiago. The source of the biosolids was sludge bio-dried to $25 \%$ moisture from the El Trebal plant in Santiago, which treats $57 \%$ of the city's wastewater. Both substrates were transferred to the nursery and air dried before being mixed to form a homogeneous substrate. The physicochemical properties of the different substrates are presented in Table 1; the main characteristics of the biosolids were as follows: $47.4 \%$ organic matter, $\mathrm{pH}$ of 6.4 , electrical conductivity of $8.09 \mathrm{dS} \mathrm{m}^{-1}$, and $79 \%$ total solids. Plants were kept under constant irrigation for 30 days to homogenize the water and physiological conditions.

Throughout the study, periodic monitoring of the water content in the substrate (WCS) was conducted as follows:

$$
W C S(\%)=\frac{F s w-D s w}{H s w-D s w} \times 100
$$

where WCS is the percentage of the water content in the substrate; Fsw is the fresh weight of the substrate (in $\mathrm{kg}$ ) taken when the control weight was measured; Hsw is the hydrated substrate weight (in $\mathrm{kg}$ ) obtained once the gravitational water was drained, and Dsw corresponds to the 
Table 1. Compositions of the experimental substrates.

\begin{tabular}{lccc}
\hline Analysis & Control & $10 \%$ biosolids & $20 \%$ biosolids \\
\hline Texture & Clay & Clay & Clay loam \\
Clay (\%) & 45.0 & 45.0 & 39.0 \\
Loam (\%) & 31.0 & 33.0 & 37.0 \\
Sand (\%) & 24.0 & 22.0 & 24.0 \\
pH susp. & 7.9 & 7.7 & 7.6 \\
CE susp. $\left(\mathrm{mS} \mathrm{cm}^{-1}\right)$ & 0.5 & 0.5 & 0.7 \\
O.M. $(\%)$ & 2.0 & 2.8 & 3.1 \\
N available $\left(\mathrm{mg} \mathrm{kg}^{-1}\right)$ & 40.0 & 38.0 & 76.0 \\
P available Olsen (mg kg-1) & 16.0 & 70.0 & 85.0 \\
K available $\left(\mathrm{mg} \mathrm{kg}^{-1}\right)$ & 510.0 & 543.0 & 553.0 \\
\hline
\end{tabular}

O.M.: Organic matter.

estimate of the dry weight of the substrate in $\mathrm{kg}$, which is obtained after drying multiple substrate samples in a forced air lab oven at $105^{\circ} \mathrm{C}$ for 48 h. WCS was monitored in a random sample of 10 individuals from each treatment.

For each substrate combination (3 levels), two irrigation regimes were applied. a) Well-watered plants (C: Control) were irrigated every two days, and WCS values over $50 \%$ were maintained throughout the experiment. b) Plants under controlled water restriction (R: Restriction) were subjected to a gradual decrease in WCS, and this restriction was maintained until day 44 when the plants reached stable WCS levels (10\% in treatments T-10 and T-20; 30\% in T-0). After 23 days under these stable levels, the plants were

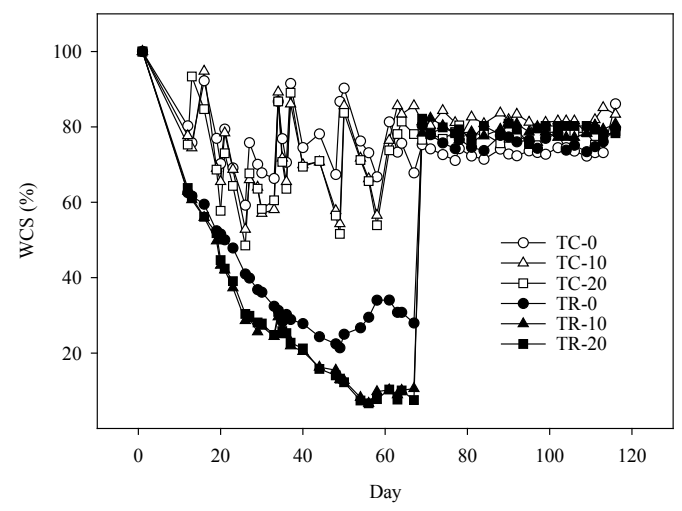

Figure 1. Substrate water content (WCS) by treatment during the experiment expressed as mean values $(n=10)$. rehydrated (day 69) to reach WCS values similar to those of the well-watered plants. To do this, 14 plants were kept well-watered, and 21 plants were subjected to water stress (Figure 1, Table 2 ) in each substrate combination. Therefore, the experimental design generated a gradient with two levels of water restriction and three substrates.

\section{Evaluation of specific water variables}

Assessments of predawn leaf water potential (Чa) and predawn leaf relative water content (RWCa) were performed based on the WCS gradients obtained during the experiment. $\Psi$ a was determined with a pressure chamber (model 1000, PMS Instruments, Corvallis, OR), and the RWCa was estimated from the ratio of the fresh tissue weight to the turgid tissue weight following the procedures described by Galmés et al. (2007). Measurements were carried out based on a random sample of six individuals from each treatment. Each measurement was taken from buds located on the upper third of each plant, which had similar characteristics in terms of the number, maturity, size and health of the leaves.

\section{Evaluation of photosynthesis and gas exchange}

When plants reached the lowest WCS level (at noon on day 61) during the experiment, net 
Table 2. Predawn water potential ( $\Psi$ a), predawn leaf relative water content (RWCa) and substrate water content (WCS) by evaluation day and treatment.

\begin{tabular}{|c|c|c|c|c|}
\hline Day & Treatment & $\Psi \mathrm{a}(\mathrm{MPa})$ & RWCa (\%) & WCS (\%) \\
\hline \multirow[t]{6}{*}{1} & TC-0 & $-0.5 \pm 0.0 \mathrm{a}$ & $85.0 \pm 5.0 \mathrm{a}$ & $100.0 \pm 0.0 \mathrm{a}$ \\
\hline & TC-10 & $-0.5 \pm 0.1 \mathrm{a}$ & $91.0 \pm 2.7 \mathrm{ab}$ & $97.0 \pm 3.0 \mathrm{a}$ \\
\hline & TC-20 & $-0.5 \pm 0.0 \mathrm{a}$ & $95.4 \pm 0.7 \mathrm{~b}$ & $100.0 \pm 0.0 \mathrm{a}$ \\
\hline & TR-0 & $-0.5 \pm 0.0 \mathrm{a}$ & $85.0 \pm 5.0 \mathrm{a}$ & $100.0 \pm 0.0 \mathrm{a}$ \\
\hline & TR-10 & $-0.5 \pm 0.1 \mathrm{a}$ & $91.0 \pm 2.7 \mathrm{ab}$ & $97.0 \pm 3.0 \mathrm{a}$ \\
\hline & TR-20 & $-0.5 \pm 0.0 \mathrm{a}$ & $95.4 \pm 0.7 b$ & $100.0 \pm 0.0 \mathrm{a}$ \\
\hline \multirow[t]{6}{*}{20} & TC-0 & $-0.3 \pm 0.0 \mathrm{~b}$ & $92.0 \pm 1.4 \mathrm{a}$ & $80.0 \pm 2.0 \mathrm{c}$ \\
\hline & TC-10 & $-0.3 \pm 0.0 \mathrm{~b}$ & $88.5 \pm 2.0 \mathrm{a}$ & $78.0 \pm 2.0 \mathrm{c}$ \\
\hline & TC-20 & $-0.4 \pm 0.0 \mathrm{~b}$ & $92.4 \pm 1.2 \mathrm{a}$ & $75.0 \pm 2.0 \mathrm{c}$ \\
\hline & TR-0 & $-0.6 \pm 0.1 \mathrm{a}$ & $91.0 \pm 1.2 \mathrm{a}$ & $51.0 \pm 3.0 \mathrm{~b}$ \\
\hline & TR-10 & $-0.6 \pm 0.0 \mathrm{a}$ & $92.2 \pm 0.7 \mathrm{a}$ & $45.0 \pm 2.0 \mathrm{a}$ \\
\hline & TR-20 & $-0.6 \pm 0.0 \mathrm{a}$ & $90.8 \pm 1.8 \mathrm{a}$ & $41.0 \pm 1.0 \mathrm{a}$ \\
\hline \multirow[t]{6}{*}{40} & TC-0 & $-0.3 \pm 0.0 \mathrm{~d}$ & $94.6 \pm 1.0 \mathrm{ab}$ & $86.0 \pm 6.0 \mathrm{~b}$ \\
\hline & TC-10 & $-0.4 \pm 0.0 \mathrm{~d}$ & $95.6 \pm 0.8 \mathrm{ab}$ & $79.0 \pm 6.0 \mathrm{~b}$ \\
\hline & TC-20 & $-0.3 \pm 0.0 \mathrm{~d}$ & $98.4 \pm 4.0 \mathrm{ab}$ & $80.0 \pm 4.0 \mathrm{~b}$ \\
\hline & TR-0 & $-3.8 \pm 0.4 \mathrm{a}$ & $64.6 \pm 10.2 \mathrm{a}$ & $27.0 \pm 2.0 \mathrm{a}$ \\
\hline & TR-10 & $-1.9 \pm 0.2 b$ & $89.0 \pm 25.9 b$ & $19.0 \pm 2.0 \mathrm{a}$ \\
\hline & TR-20 & $-1.4 \pm 0.1 \mathrm{c}$ & $88.8 \pm 1.0 \mathrm{ab}$ & $20.0 \pm 0.0 \mathrm{a}$ \\
\hline \multirow[t]{6}{*}{61} & TC-0 & $-0.3 \pm 0.0 \mathrm{~d}$ & $92.5 \pm 2.5 \mathrm{~b}$ & $88.0 \pm 2.0 \mathrm{c}$ \\
\hline & TC-10 & $-0.3 \pm 0.0 \mathrm{~d}$ & $93.4 \pm 1.5 \mathrm{~b}$ & $90.0 \pm 2.0 \mathrm{c}$ \\
\hline & TC-20 & $-0.3 \pm 0.0 \mathrm{~d}$ & $92.4 \pm 1.4 \mathrm{~b}$ & $93.0 \pm 3.0 \mathrm{c}$ \\
\hline & TR-0 & $-4.8 \pm 0.4 b$ & $77.8 \pm 3.6 \mathrm{a}$ & $30.0 \pm 2.0 \mathrm{~b}$ \\
\hline & TR-10 & $-5.6 \pm 0.2 \mathrm{a}$ & $81.9 \pm 2.9 \mathrm{a}$ & $9.0 \pm 1.0 \mathrm{a}$ \\
\hline & TR-20 & $-3.9 \pm 0.1 \mathrm{c}$ & $75.7 \pm 2.9 \mathrm{a}$ & $10.0 \pm 1.0 \mathrm{a}$ \\
\hline \multirow[t]{6}{*}{117} & TC-0 & $-0.3 \pm 0.0 \mathrm{a}$ & $95.1 \pm 0.7 \mathrm{a}$ & $100.0 \pm 2.0 \mathrm{c}$ \\
\hline & TC-10 & $-0.3 \pm 0.0 \mathrm{a}$ & $97.0 \pm 1.1 \mathrm{a}$ & $90.0 \pm 3.0 \mathrm{ab}$ \\
\hline & TC-20 & $-0.3 \pm 0.0 \mathrm{a}$ & $95.6 \pm 1.1 \mathrm{a}$ & $90.0 \pm 2.0 \mathrm{ab}$ \\
\hline & TR-0 & $-0.3 \pm 0.0 \mathrm{a}$ & $95.5 \pm 1.1 \mathrm{a}$ & $96.0 \pm 3.0 \mathrm{bc}$ \\
\hline & TR-10 & $-0.3 \pm 0.0 \mathrm{a}$ & $95.6 \pm 0.9 \mathrm{a}$ & $89.0 \pm 2.0 \mathrm{a}$ \\
\hline & TR-20 & $-0.3 \pm 0.0 \mathrm{a}$ & $97.6 \pm 0.6 \mathrm{a}$ & $85.0 \pm 2.0 \mathrm{a}$ \\
\hline
\end{tabular}

Values expressed as means \pm standard errors $(n=6)$. Different letters indicate significant differences among treatments for each evaluation day (Duncan's test, $\mathrm{P} \leq 0.05$ ).

photosynthesis (An), stomatal conductance (gs), transpiration (E) and internal $\mathrm{CO}_{2}$ concentration (Ci) were calculated using an ADC Bioscientific LCpro+ system. Measurements were taken on five of the leaves on the upper third of the plants per treatment (two levels of irrigation and three levels of substrate) for a total of 30 measurements.

\section{Evaluation of growth traits and biomass distribution}

Root collar diameter (RCD) and total height were periodically monitored throughout the study.
At the beginning of the experiment, all of the plants were marked on the lower section of their main stem (root collar) to track the development in both traits. The main stem of each plant was used for the height measurement, and the distance between the mark and the apex of the stem was measured at each opportunity using a $1 \mathrm{~mm}$ precision measuring tape. A Vernier caliper with a $0.1 \mathrm{~mm}$ resolution was used to calculate RCD.

The biomass of the plant components (leaves, shoots and roots) was determined at the beginning and end of the water restriction period. In each 
evaluation, a random sample of five individuals per treatment was analyzed, and for each selected plant, the root system was separated from the aerial part, which in turn was separated into leaves and woody material. Samples were dried at $65^{\circ} \mathrm{C}$ in a forced air oven until they reached a stable weight, and the total biomass per component and the shoot:root biomass ratio were obtained.

\section{Statistical analysis}

Differences in the biomass, photosynthesis, and gas exchange measurements were tested with analysis of variance using a completely random two $\mathrm{x}$ three factorial design (irrigation regime and biosolid doses). Plant growth was analyzed by repeated measures ANOVA, which evaluated the statistical significance of the differences among the mean values of each treatment using Duncan's test $(\mathrm{P} \leq 0.05)$.

\section{Results}

Plant water status during the study

The WCS values of the well-watered plants were maintained above $50 \%$ for the entire experiment (Figure 1). Under these conditions, the predawn Ya and predawn leaf RWCa showed no significant differences as a result of the application of biosolids with $\Psi$ a values around -0.3 MPa and RWCa values above $85 \%$ (Table 2). However, from the beginning of the experiment, the WCS values of the plants under water restriction progressively decreased (from 27 to 19\%), which resulted in a decrease in the average $\Psi$ a and RWCa values at day 40. During this period, statistically significant differences $(\mathrm{P}=0.01)$ among the water-restricted treatments were observed. For example, the treatment without biosolids presented the lowest $\Psi \mathrm{a}(-3.8 \mathrm{MPa})$ and RWCa (64.6\%) values, which were significantly different from the treatments with biosolids (TR10: -1.9 MPa for $\Psi \mathrm{a}$ and $89.0 \%$ for RWCa; TR-20: -1.4 MPa for $\Psi a$ and $88.8 \%$ for RWCa). On day
61, the plants in the water restriction treatment registered the lowest WCS levels (TR-0: 30.0\%; TR-10: 9.0\%; TR-20: 10.0\%) and the lowest $\Psi$ a and RWCa values. The substrate treated with $20 \%$ biosolids exhibited reduced water stress ( $\Psi$ a of $-3.9 \mathrm{MPa}$ ), but a different situation occurred in the $10 \%$ biosolids treatment, which presented an average $\Psi$ a value of -5.6 MPa. However, the treatment without biosolids exhibited moderate water stress ( $\Psi$ a of $-4.8 \mathrm{MPa}$ ) as well as a significantly higher WCS value than the other treatments under water restriction. Additionally, the water available to the plant, evaluated through the relationship between $\Psi a$ and WCS (trend lines), was greater in the treatments with biosolid additions (Figure 2), which presented higher organic matter contents and changes in their textural properties (Table 1). After day 61, the water restriction treatments were returned to the $\Psi$ a and RWCa values observed at the beginning of the experiment, and the WCS values increased.

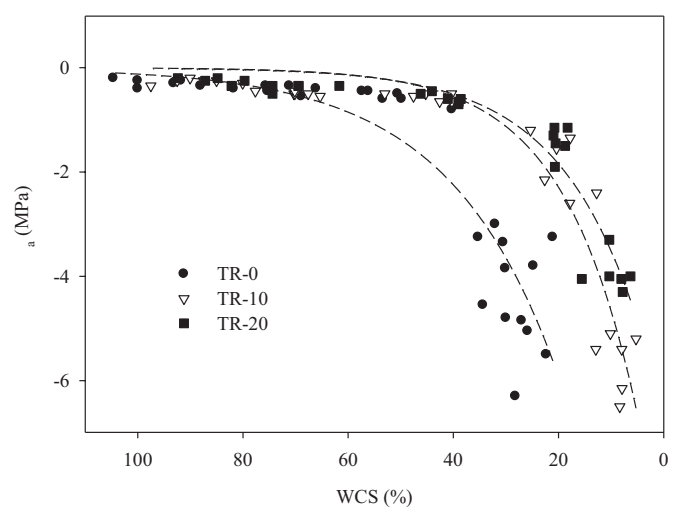

Figure 2. Predawn water potential ( $\Psi$ a) according to the substrate water content values (WCS) in the water restriction treatments and the trend lines for each treatment. Values represent the $\Psi \mathrm{a}$ and WCS measurements taken throughout the experiment.

\section{Photosynthesis and gas exchange}

During the evaluation of gas exchange at the end of the water stress period (day 61), the well-watered treatments showed average net photosynthesis 
(An) values of over $18 \mathrm{~mol} \mathrm{~m}^{-2} \mathrm{~s}^{-1}$, mean values of stomatal conductance (gs) over $420 \mathrm{mmol} \mathrm{m}^{-2} \mathrm{~s}^{-1}$ and average $E$ values over $16 \mathrm{mmol} \mathrm{m}^{-2} \mathrm{~s}^{-1}$ while the Ci levels were approximately $270 \mathrm{~mol} \mathrm{~m}^{-2} \mathrm{~s}^{-1}$ (Figure 3). Within this group, the application of biosolids resulted in a proportional increase in An, but it was not significantly different $(\mathrm{P}=0.04)$ from the value observed in the treatment without biosolids. Furthermore, the An, gs and E values in the group under water restriction during this period were significantly lower $(\mathrm{P} \leq 0.01)$ than those observed in the well-watered treatments, but no significant differences were observed as a result of the application of biosolids.

\section{Biomass growth and distribution}

At the beginning of the experiment, espino plants had RCD values between 4.3 and $5.1 \mathrm{~mm}$, and the well-watered plants maintained positive growth throughout the study (Figure 4A). Within these plants, the $20 \%$ biosolids treatment (TC-20) registered a significantly greater (48\%) RCD value at the end of the trial than those obtained from the treatments without biosolids, whereas the $10 \%$ biosolids treatment presented a significant increase of only $27 \%$. The plants subject to the water restriction treatments also maintained positive increases, but they were smaller than those obtained in the well-watered treatments. Therefore, the $20 \%$ biosolids treatment showed a $36 \%$ greater RCD value at the end of the trial than that obtained without biosolids while in the $10 \%$ biosolids treatment, this difference was $26 \%$.

The total height response was similar to that observed for RCD. At the beginning of the experiment, the espino plants were between 30 and $35 \mathrm{~cm}$ tall, and at the end of the study, the well-watered plants subject to the $20 \%$ and $10 \%$ biosolids treatments presented significantly $(\mathrm{P}=0.005)$ greater heights ( 35 and $40 \%$ ) than the treatment without biosolids (Figure 4B). Under water restriction, the observed increases were of lower magnitude than those in the well-watered treatments. Unlike what happened with RCD, the application of biosolids had no significant effect on the increase in total height.

At end of the experiment, the well-watered plants exhibited a significant increase $(\mathrm{P}=0.001)$ in all biomass components (Table 3 ). The biosolid applications had a significant effect on the increase in biomass (more than 70\%) of the aerial parts (leaves and shoot), and the plants under water restriction yielded lower values (50\%) than those obtained in the well-watered plants, especially for total biomass. The shoot:root biomass ratio significantly decreased $(\mathrm{P}=0.03)$ in the treatments without biosolid applications under both levels of irrigation.

\section{Discussion}

The observed response in the predawn $\Psi$ a and predawn RWCa values in well-watered and waterstressed plants is consistent with that observed in several studies of Mediterranean species under stress conditions (Pardos et al., 2005; Galmés et al., 2007; Gallé et al., 2007; Donoso et al, 2011). The application of biosolids to the substrate exerted a positive effect on the response of the plants to water stress; during the period when plants entered the water restriction phase (day 40), the biosolid application treatments resulted in greater predawn water potential than that observed in the treatment without biosolids. Later, when the water restriction was more severe (day 61), this result was also observed in the TR-20 but not in the TR-10 treatment, which presented more severe water restriction conditions indicated by the low WCS values of the plants (9\%). However, the results suggest that the application of biosolids to the substrate promotes improved plant hydration under conditions of water stress, and this may be attributed to changes in the physical properties of the substrate, mainly increased organic matter content and modified texture, that improved its ability to deliver water to the plants. Such substrate conditions can be crucial to reforesta- 

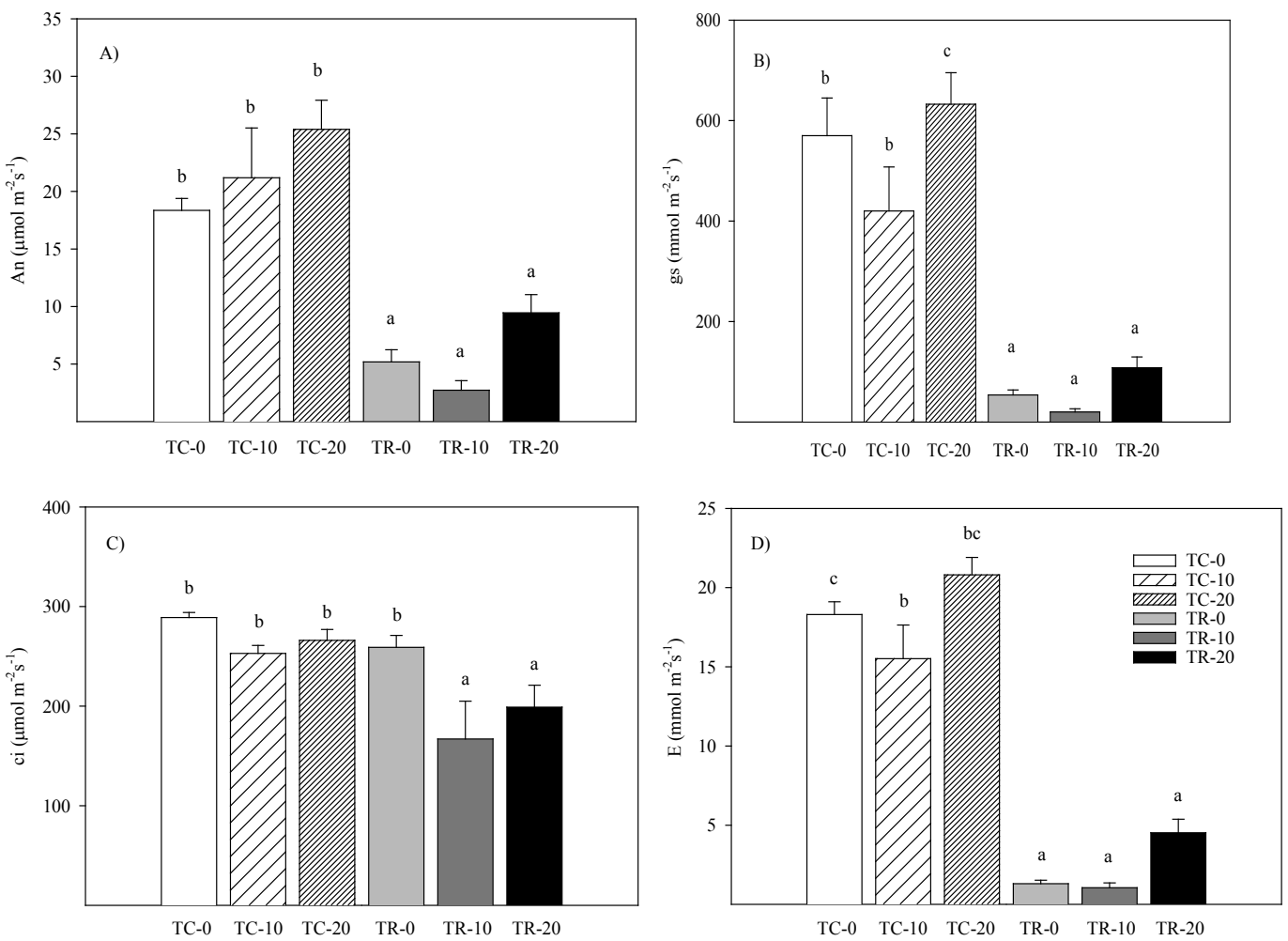

Figure 3. Gas exchange trials on day 61 of the evaluation. A) Net photosynthesis $=$ An; B) stomatal conductance $=$ gs; C) internal $\mathrm{CO}_{2}$ concentration $\left.=\mathrm{Ci} ; \mathrm{D}\right)$ Transpiration $=\mathrm{E}$. Values are expressed as means \pm standard errors $(\mathrm{n}=5)$, and different letters indicate significant differences among treatments (Duncan's test, $\mathrm{P} \leq 0.05$ ).
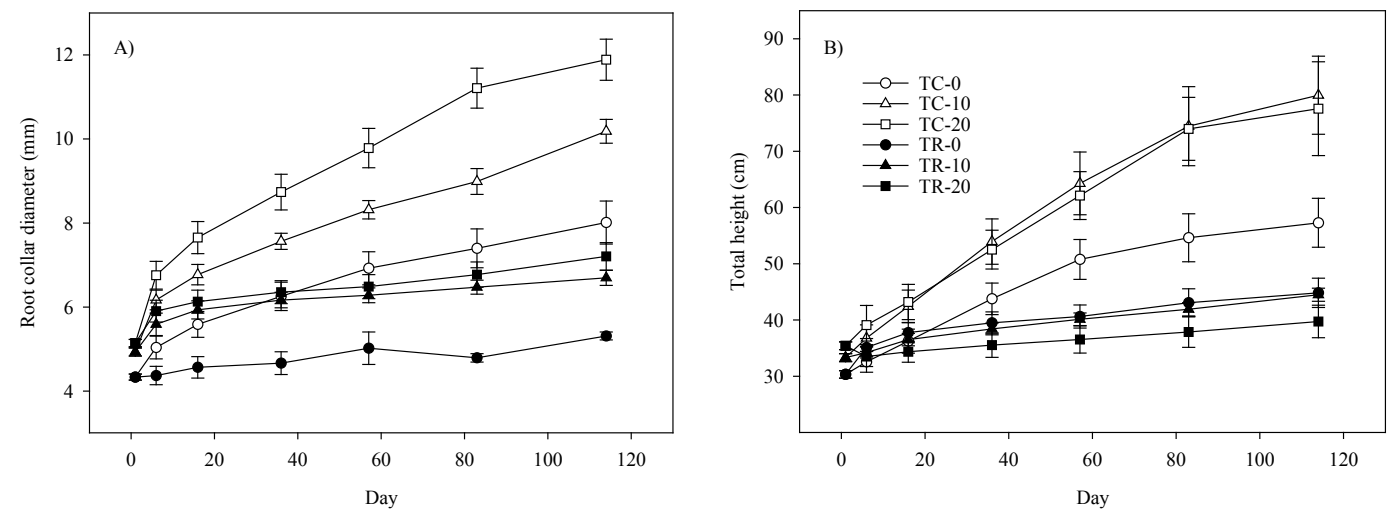

Figure 4. Plant development by treatment during the experiment. A) Growth in root collar diameter (RCD) and B) total height. Values are expressed as means \pm standard errors $(\mathrm{n}=10)$. 
Table 3. Plant biomass by component, evaluation period and treatment (two irrigation regimes: well-watered (TC) and water restriction (TR); three levels of biosolid application: $0 \%, 10 \%$ and $20 \%$ ).

\begin{tabular}{|c|c|c|c|}
\hline Component & Treatment & Day 1 & Day 70 \\
\hline \multirow{6}{*}{$\begin{array}{l}\text { Leaves } \\
\left.\text { (g plant }^{-1}\right)\end{array}$} & TC-0 & $1.0 \pm 0.1 \mathrm{a}$ & $3.7 \pm 0.3 \mathrm{~b}$ \\
\hline & TC-10 & $1.1 \pm 0.2 \mathrm{a}$ & $7.8 \pm 1.3 \mathrm{c}$ \\
\hline & TC-20 & $1.2 \pm 0.2 \mathrm{a}$ & $7.2 \pm 1.0 \mathrm{c}$ \\
\hline & TR-0 & $1.0 \pm 0.1 \mathrm{a}$ & $0.7 \pm 0.1 \mathrm{a}$ \\
\hline & TR-10 & $1.1 \pm 0.2 \mathrm{a}$ & $1.6 \pm 0.3 \mathrm{ab}$ \\
\hline & TR-20 & $1.2 \pm 0.2 \mathrm{a}$ & $2.9 \pm 0.3 b$ \\
\hline \multirow{6}{*}{$\begin{array}{l}\text { Shoots } \\
\left(\text { g plant }^{-1}\right)\end{array}$} & TC-0 & $1.8 \pm 0.2 \mathrm{a}$ & $6.0 \pm 0.7 \mathrm{ab}$ \\
\hline & TC-10 & $1.9 \pm 0.6 \mathrm{a}$ & $11.6 \pm 3.0 \mathrm{c}$ \\
\hline & TC-20 & $2.0 \pm 0.3 \mathrm{a}$ & $9.6 \pm 1.0 \mathrm{bc}$ \\
\hline & TR-0 & $1.8 \pm 0.2 \mathrm{a}$ & $4.2 \pm 0.3 \mathrm{a}$ \\
\hline & TR-10 & $1.9 \pm 0.6 \mathrm{a}$ & $4.6 \pm 0.6 \mathrm{a}$ \\
\hline & TR-20 & $2.0 \pm 0.3 \mathrm{a}$ & $4.8 \pm 0.5 \mathrm{a}$ \\
\hline \multirow{6}{*}{$\begin{array}{l}\text { Root } \\
\left.\text { (g plant }^{-1}\right)\end{array}$} & TC-0 & $2.1 \pm 0.2 \mathrm{a}$ & $17.1 \pm 1.5 b$ \\
\hline & TC-10 & $2.9 \pm 0.9 \mathrm{a}$ & $15.3 \pm 2.2 b$ \\
\hline & TC-20 & $2.4 \pm 0.4 \mathrm{a}$ & $9.8 \pm 0.5 \mathrm{a}$ \\
\hline & TR-0 & $2.1 \pm 0.2 \mathrm{a}$ & $6.8 \pm 0.2 \mathrm{a}$ \\
\hline & TR-10 & $2.9 \pm 0.9 \mathrm{a}$ & $7.4 \pm 0.9 \mathrm{a}$ \\
\hline & TR-20 & $2.4 \pm 0.4 \mathrm{a}$ & $7.2 \pm 0.4 \mathrm{a}$ \\
\hline \multirow{6}{*}{$\begin{array}{l}\text { Total } \\
\left(\text { g plant }^{-1}\right)\end{array}$} & TC-0 & $5.0 \pm 0.3 \mathrm{a}$ & $26.8 \pm 2.2 \mathrm{~b}$ \\
\hline & TC-10 & $6.0 \pm 1.1 \mathrm{a}$ & $34.8 \pm 6.4 b$ \\
\hline & TC-20 & $5.6 \pm 0.5 \mathrm{a}$ & $26.6 \pm 2.2 \mathrm{~b}$ \\
\hline & TR-0 & $5.0 \pm 0.3 \mathrm{a}$ & $11.7 \pm 0.4 \mathrm{a}$ \\
\hline & TR-10 & $6.0 \pm 1.1 \mathrm{a}$ & $13.5 \pm 1.0 \mathrm{a}$ \\
\hline & TR-20 & $5.6 \pm 0.5 \mathrm{a}$ & $15.0 \pm 0.8 \mathrm{a}$ \\
\hline \multirow{6}{*}{$\begin{array}{l}\text { Shoot:root } \\
\text { ratio }\end{array}$} & TC-0 & $1.3 \pm 0.1 \mathrm{a}$ & $0.6 \pm 0.0 \mathrm{a}$ \\
\hline & TC-10 & $1.0 \pm 0.1 \mathrm{a}$ & $1.3 \pm 0.1 \mathrm{c}$ \\
\hline & TC-20 & $1.3 \pm 0.1 \mathrm{a}$ & $1.7 \pm 0.1 \mathrm{~d}$ \\
\hline & TR-0 & $1.3 \pm 0.1 \mathrm{a}$ & $0.7 \pm 0.1 \mathrm{a}$ \\
\hline & TR-10 & $1.0 \pm 0.1 \mathrm{a}$ & $0.8 \pm 0.2 \mathrm{abc}$ \\
\hline & TR-20 & $1.3 \pm 0.1 \mathrm{a}$ & $1.1 \pm 0.1 \mathrm{bc}$ \\
\hline
\end{tabular}

Values expressed as means \pm standard errors $(n=5)$. Different letters indicate significant differences among treatments for each component (Duncan's test, $\mathrm{P} \leq 0.05$ ).

tion in areas with clay soils, such as those in the northern part of Santiago, as these soils present low permeability, low organic matter content and tend toward compaction. The application of organic matter through biosolids helps address the most important limitation to plant growth, the lack of available water, as it promotes the renovation of the physical soil characteristics and improves the chemical properties (Henry et al., 1994; Valdecantos et al., 2011). This soil moisture response differs from that obtained by Fuentes et al. (2007b), who observed that higher biosolid application rates resulted in a reduced $\Psi$ a values in Quercus ilex plants compared to those observed in untreated plants. This behavior was related to decreased osmotic potential in the soil as a result of an increased concentration of salts in the roots. 
In terms of the gas exchange parameters obtained from the evaluation on day 61, significantly higher An, gs and E rates were observed in the wellwatered treatments than in the water restriction treatments, and the application of biosolids in the well-hydrated substrate led to a proportional increase in An. This response was associated with a significant increase in foliar biomass that ultimately resulted in an increase in the carbon balance, which promoted greater growth and biomass accumulation in the aerial components. In contrast, a decrease in WCS and $\Psi$ a values in the treatments under water restriction caused a reduction in An, gs and $\mathrm{E}$, which ultimately reduced growth and the average values of almost all of the biomass components. According to Flexas et al. (2006), limited growth and biomass accumulation due to water stress are mainly caused by a reduced carbon balance in the plant; a condition that might be caused by a decrease in An as a result of a decrease in gs. This is consistent with the results obtained in this study for the waterrestricted treatments.

The most important results from the biosolid applications were increased growth and aerial biomass accumulation, which have already been observed in other species (Pascual et al., 2004; Antolin et al., 2005; Antolin et al., 2010; Valdecantos et al., 2011). This response, in which biosolids stimulate plant growth, is primarily related to an increase in nutrient levels in the substrate (Pascual et al., 2004; Antolin et al., 2010). In this study, the biosolid applications positively affected RCD and total plant height, and under well-watered conditions, both variables significantly increased.

Finally, these results suggest that the natural behavior of espino is to first promote investment in the root followed by the aerial portion because the shoot:root biomass ratio decreased significantly under both irrigation conditions (in the absence of biosolids in the substrate), resulting in an important advantage during episodes of water restriction. However, this ability to cope with stress can be significantly modified by the application of biosolids as, under both irrigation conditions, the biosolids produced a proportional increase in the shoot:root ratio, mainly due to an increase in the biomass of leaves and shoots. Valdecantos et al. (2011) also observed a significant increase in the aerial biomass of Pinus halepensis seedlings amended with biosolids in liquid form, a response that was accompanied by an increase in leaf biomass and a decrease in the root portion that ultimately resulted in a significant increase in the stem:root ratio. This behavior has been observed in numerous studies, which have reported increases in the shoot:root ratio together with an improvement in the nutritional status of the soil or growing media (Proe and Millard, 1994; Colpaert et al., 1996). This can mean increased susceptibility of seedlings to water stress due to an increase in the evapotranspiration surface area, so to prevent this situation, further research into the application of biosolids combined with other treatments should be performed to ultimately correct the increase in the shoot:root ratio. Alternatively, it is possible that biosolids should be just applied to the surface to minimize their contact with the roots.

In conclusion, the application of biosolids to clay substrates improves water delivery to plants, which promotes better hydration during episodes of water restriction. Additionally, the application of biosolids stimulates aerial plant growth and increases the shoot:root biomass ratio, which may compromise the ability of a plant to cope in water-restricted environments. Therefore, it is necessary to delve deeper into the dynamics of biosolid application and the possible consequences for biomass distribution under field conditions.

\section{Acknowledgements}

We thank Aguas Andinas S.A. and the Programa de Bosques Mediterráneos de la Facultad de Ciencias Forestales y de la Conservación de la Naturaleza, Universidad de Chile, for the contributions made to this study. 


\title{
Resumen
}

\begin{abstract}
S. Donoso, K. Peña-Rojas, C. Pacheco, S. Durán, R. Santelices y C. Mascaró. 2015. Respuesta fisiológica y de crecimiento en plantas de Acacia caven (Mol.) bajo diferentes niveles de aplicación de biosólido y restricción hídrica. Cien. Inv. Agr. 42(2):273-283. Acacia caven (Mol.) Mol. (Leguminosae), generalmente conocido como "espino", es una de las especies arbóreas más comunes en la región mediterránea de Chile. Esta especie crece en suelos nutricionalmente pobres y con una baja disponibilidad hídrica estival, que dificulta el proceso de establecimiento de nuevas plántulas. Para investigar los efectos de la restricción hídrica y el potencial benéfico de la aplicación de biosólidos (biosolido-seco a $25 \%$ de humedad) en el crecimiento de la planta, se estableció un ensayo con un diseño bifactorial completamente al azar en vivero bajo condiciones controladas. Se aplicaron dos tipos de riego (plantas bien regadas y restricción hídrica controlada) y tres dosis de aplicación de biosólidos en un sustrato arcilloso $(0: 100,10: 90$ y 20:80). La evaluación fisiológica (potencial hídrico a pre-alba, fotosíntesis e intercambio gaseoso) fue realizada en momentos representativos del gradiente de restricción hídrica, y fue complementada con mediciones de crecimiento y distribución de biomasa. Cuando las plantas entraron en la fase de restricción hídrica, aquellas que se crecieron en un sustrato con biosólido, presentaron una mejor condición hídrica en comparación con las plantas sin biosólido. Esto se debe a un aumento en el contenido de materia orgánica y a un cambio en las características texturales del sustrato original, incrementando la capacidad para suministrar agua a las plantas. Adicionalmente, la aplicación de biosólidos promovió el crecimiento de hojas y tallos en plantas bien regadas, e incremento la relación tallo: raíz, que es una desventaja para la tolerancia al estrés hídrico.
\end{abstract}

Palabras clave: Biomasa, potencial hídrico a pre-alba, fotosíntesis, relación raíz tallo, restricción hídrica.

\section{References}

Antolín, M. C., I. Pascual, C. García, A. Polo, and M. Sánchez-Díaz. 2005. Growth, yield and solute content of barley in soils treated with sewage sludge under semiarid mediterranean conditions. Field Crop Res. 94: 224-237.

Antolín, M. C., I. Muro, and M. Sánchez-Díaz. 2010. Application of sewage sludge improves growth, photosynthesis and antioxidant activities of nodulated alfalfa plants under drought conditions. Environmental and Experimental Botany 68: 75-82.

CIREN. 1996. Estudio Agrológico Región Metropolitana. Descripciones de suelos, materiales y símbolos. Publicación $\mathrm{N}^{0} 115$. Centro de Información de Recursos Naturales (CIREN). Santiago, Chile. 425 p.

Cogger, C., P. Sullivan, C. Henry, and K. Dorsey. 2000. Biosolids Management Guidelines for
Washington State. Washington State Department of Ecology. Washington, United States. 235 pp.

Colpaert, J.V., A. Van Laere, and J.A. Van Assche. 1996. Carbon and nitrogen allocation in ectomycorrhizal and non-mycorrhizal Pinus sylvestris L. seedlings. Tree Physiology 16: 787-793.

Donoso, S., K. Peña, C. Pacheco, G. Luna, and A. Aguirre. 2011. Respuesta fisiológica y de crecimiento en plantas de Quillaja saponaria y Cryptocarya alba sometidas a restricción hídrica. Bosque 32: 187-195.

Flexas, J., J. Bota, J. Galmés, H. Medrano, and M. Ribas-Carbó. 2006. Keeping a positive carbon balance under adverse conditions: responses of photosynthesis and respiration to water stress. Physiol. Plantarum 127: 343-352.

Fuentes, D., K.B. Disante, A. Valdecantos, J. Cortina, and V.R. Vallejo. 2007a. Response of Pinus halepensis Mill. seedlings to biosolids enriched 
with $\mathrm{Cu}, \mathrm{Ni}$ and $\mathrm{Zn}$ in three Mediterranean forest soils. Environmental Pollution 145: 316-323.

Fuentes, D., A. Valdecantos, J. Cortina, and V.R. Vallejo. 2007b. Seedling performance in sewage sludge-amended degraded mediterranean woodlands. Ecological Engineering 31: 281-291.

Galmés, J., J. Flexas, R. Savé, and H. Medrano. 2007. Water relations and stomatal characteristics of Mediterranean plants with different growth forms and leaf habits: responses to water stress and recovery. Plant Soil 290: 139-155.

Gallé, A., P. Haldimann, and U. Feller. 2007. Photosynthetic performance and water relations in young pubescent oak (Quercus pubescens) trees during drought stress and recovery. New Phytol. 174: 799-810.

Henry, C.L., D.W. Cole, and R.B. Harrison. 1994. Use of municipal sludge to restore and improve site productivity in forestry: the Pack Forest sludge research program. Forest Ecol. Manag. 66: 137-149.

Larcheveque, M., V. Baldy, N. Montés, C. Fernandez, G. Bonin, and C. Ballini. 2006. Short-term effects of sewage-sludge compost on a degraded Mediterranean soil. Soil Sci. Soc. Am. J. 70: 1178-1188.

Pardos, M., M.D. Jiménez, I. Aranda, J. Puértolas, and J.A. Pardos. 2005. Water relations of cork oak (Quercus suber L.) seedlings in response to shading and moderate drought. Ann. For. Sci. 62: 377-384.

Pascual, I., M.C. Antolín, C. García, A. Polo, and M. Sánchez-Díaz. 2004. Plant availability of heavy metals in a soil amended with a high dose os sewage sludge under drought conditions. Biol. Fert. Soils 40: 291-299.

Paz, C., O. Henríquez, and R. Freres. 2007. Posibilidades de aplicación de lodos o biosólidos a los suelos del sector norte de la Región Metropolitana de Santiago. Revista de Geografía Norte Grande 37: 35-45.

Proe, M. F., and P. Millard. 1994. Relationships between nutrient supply, nitrogen portioning and growth in young Sitka spruce (Picea sitchensis). Tree Physiology 14: 75-88.

Valdecantos, A., J. Cortina, and V.R. Vallejo. 2011. Differential field response of two mediterranean tree species to inputs of sewage sludge at the seedling stage. Ecological Engineering 37: 13501359.

Villar-Salvador, P., R. Planelles, J. Oliet, J. L. Peñuelas-Rubira, D. F. Jacobs, and M. González. 2004. Drought tolerance and transplanting performance of holm oak (Quercus ilex) seedlings after drought hardening in the nursery. Tree Physiol. 24: 1147-1155. 
